\title{
Genetic variation and relationship in Staphylococcus aureus isolates from human and food samples using random amplified polymorphic DNAs
}

\author{
Olorunfemi, O.B. ${ }^{*}$ Onasanya, A.A. and Adetuyi, F.C. \\ Microbiology Department, Federal University of Technology. P.M.B.704, Akure.
}

Accepted 13 May, 2005

\begin{abstract}
A genetic characterization of 18 different isolates of Staphylococcus aureus using random amplified polymorphic DNAs (RAPDs) was carried out. Out of one hundred primers tested, ten showed polymorphism. The amplification reactions with the 10 primers generated 88 bands, 51 of which is polymorphic with band size ranging between 200 and 3,000 bp. Variation and relatedness between different isolates were determined by converting RAPD data into a Jaccard similarity matrix and analysed by UPGMA (unweighted pair-group method, arithmetic average) to produce completely twelve different groups at $100 \%$ Jaccard similarity and at $50 \%$ coefficient of similarity. The isolates were classified into two major groups, the first comprises of mildly and weakly virulence, while the other group are the highly virulence Staphylococci. The results demonstrated that the RAPD technique may be of great use in the classification of $S$. aureus.
\end{abstract}

Key words: Staphylococcus aureus, Genetic classification, RAPD technique.

\section{INTRODUCTION}

Staphylococcus aureus are Gram positive cocci in clusters. They cause a variety of superficial and deep infections, in most cases pus-forming in man. They are frequently found as contaminants in clinical specimens taken from the body surfaces, for example, swab from skin, nose, throat, wounds, burns and bed-sores. Occasionally, S. aureus acts as opportunistic pathogens and cause infections of the urinary tract, respiratory tract and intestinal tract (Coltman, 1981). The pathogenicity of $S$. aureus as indicated by Stokes and Ridgway (1980) include, abscesses, boils, conjunctivitis especially in newborn, cross-infections in hospitals septicaemia, mastitis and food poisoning (of meats, milk and milk products). S. aureus produces enzymes and toxins which include coagulase, an enzyme that clots plasma and coats staphylococcal cells, which prevents the cells from being phagocytosed and destroyed by macrophages.

\footnotetext{
*Corresponding author. E-mail: feyifemi2003@yahoo.co.uk.
}

Sng et al. (1981) presented those characteristics useful for identification of $S$. aureus, as golden colony, pigmentation, production of coagulase, deoxyribonulease, phosphatase, $\alpha-, \beta-$, and $\delta$-heamolytic toxins, leucocidin, fibrinolysin and hyaluronidase.

All the identification and classification methods of characterizing $S$. aureus are complex, time-consuming and requiring basic knowledge of biochemistry or molecular biology of the species being studied (Thottappilly et al., 1999). Kloos and Schleifer (1981) described $S$. aureus as a variable bacterium with many morphological variants. It is of importance in epidemiology and ecology to be able to identify bacterial species and strains accurately. Rapid identification and classification of bacteria is normally carried out by morphology, nutritional requirements, antibiotic resistance, isoenzyme comparison, phage sensitivity (Eisenstein, 1990) and more recently DNA based methods, particularly rRNA sequences (Woese,1986) and strain-specific fluorescent oligonucleotides (Delong et al.,1990). Each of these methods has specific applications and advantages. 
Table 1. S. aureus isolates used in this study.

\begin{tabular}{|c|c|c|c|c|c|}
\hline S/N & Isolate Code & Host & Source & Virulence & Disease symptom \\
\hline 1 & $1 \mathrm{SaUCH}$ & Man & Skin wound & $\mathrm{Mv}$ & Milky pus \\
2 & $5 \mathrm{SaUCH}$ & Woman & Skin wound & $\mathrm{Mv}$ & Milky pus \\
3 & $6 \mathrm{SaUCH}$ & Man & Skin wound & $\mathrm{Mv}$ & Milky pus \\
4 & $17 \mathrm{SaUCH}$ & Woman & Nose swab & $\mathrm{Hv}$ & Yellowish mucus \\
5 & $19 \mathrm{SaUCH}$ & Man & Nose swab & $\mathrm{Mv}$ & Yellowish mucus \\
6 & $20 \mathrm{SaUCH}$ & Man & Nose swab & $\mathrm{Mv}$ & Yellowish mucus \\
7 & $12 \mathrm{SaUCH}$ & Woman & Vagina swab & $\mathrm{Hv}$ & Whitish discharge \\
8 & $13 \mathrm{SaUCH}$ & Woman & Vagina swab & $\mathrm{Hv}$ & Whitish discharge \\
9 & $14 \mathrm{SaUCH}$ & Woman & Vagina swab & $\mathrm{Mv}$ & Whitish discharge \\
10 & $25 \mathrm{SaUCH}$ & Man & Ear swab & $\mathrm{Wv}$ & Brownish pus \\
11 & $26 \mathrm{SaUCH}$ & Woman & Ear swab & $\mathrm{Mv}$ & Brownish pus \\
12 & $28 \mathrm{SaUCH}$ & Man & Ear swab & $\mathrm{Mv}$ & Brownish pus \\
13 & $4 \mathrm{SaUCH}$ & Man & Urine & $\mathrm{Hv}$ & Brownish pus \\
14 & $7 \mathrm{SaUCH}$ & Woman & Urine & $\mathrm{Mv}$ & Brownish pus \\
15 & $8 \mathrm{SaUCH}$ & Man & Urine & $\mathrm{Hv}$ & Brownish pus \\
16 & $33 \mathrm{SaUCH}$ & Man & Stool & $\mathrm{Hv}$ & Watery stool \\
17 & $34 \mathrm{SaUCH}$ & Man & Stool & $\mathrm{Hv}$ & Watery stool \\
18 & $14 \mathrm{IT}$ & Soybean & Soy-milk & $\mathrm{Mv}$ & Watery stool \\
\hline
\end{tabular}

Keyword: Hv---highly virulence.

Mv---mildly virulence.

Wv---weakly virulence.

However, closely related isolates are difficult to identify and differentiate using the biochemical methods. For effective chemotherapeutic treatments of infections or disease caused by this organism, the degree of virulence of different strains needed to be determined. The objective of this study is to carry out a genetic characterization of different isolates of $\mathrm{S}$. aureus using random amplified polymorphic DNA polymerase chain reaction (RAPD-PCR). This RAPD procedure works with anonymous genomic markers, requires only small amounts of DNA and when compared with the biochemical methods, is simpler, very sensitive, cheaper, faster and less labour intensive than other DNA maker methodologies.

\section{MATERIALS AND METHODS}

\section{Source of S. aureus}

Of the 18 pure isolates of $S$. aureus used in this work, 17 were human clinical samples obtained from the Microbiology Section of the University College Teaching Hospital (UCH) Ibadan, Nigeria and the 18th from the Seed Health Unit, International Institute of Tropical Agriculture (IITA) Ibadan, Nigeria (Table 1). They were stored according to the method of Gore and Walsh (1964).

\section{Cell Propagation}

S. aureus isolates were first propagated using a modified procedure developed by Kado and Heskett (1970). About $75 \mathrm{ml}$ of nutrient broth $(\mathrm{pH} 7.5)$ was prepared inside a conical flask. About $200 \mu \mathrm{l}$ of nutrient broth containing the isolate was transferred into the freshly prepared broth and kept under constant shaking at $37^{\circ} \mathrm{C}$ for $24 \mathrm{~h}$ for bacterial growth. The bacterial cell was removed by centrifugation, washed with $0.1 \mathrm{mM}$ Tris- EDTA and kept at $-20^{\circ} \mathrm{C}$ for DNA extraction.

\section{Genomic DNA Extraction}

DNA extraction was according to Roeder and Broda (1987) with some modifications. Approximately $0.3 \mathrm{~g}$ of washed bacterial cell was suspended in $200 \mu \mathrm{l}$ of $2 \mathrm{X}$ CTAB buffer $(50 \mathrm{mM}$ Tris, $\mathrm{pH}$ 8.0, $0.7 \mathrm{mM} \mathrm{NaCl}, 10 \mathrm{mM}$ EDTA, $2 \%$ hexadecyltri-methylammonium bromide, $0.1 \%$ 2-mercaptoethanol), followed by $100 \mu \mathrm{l}$ of $20 \%$ sodium dodecyl sulfate and incubated at $65^{\circ} \mathrm{C}$ for $20 \mathrm{~min}$. DNA was purified by two extraction with phenol: chloroform: isoamyl alcohol $(24: 25: 1)$ and precipitated with $-20^{\circ} \mathrm{C}$ absolute ethanol. After washing with $70 \%$ ethanol, the DNA was dried and re-suspended in $200 \mu \mathrm{l}$ of sterile distilled water. DNA concentration was measured using a DU-65UV spectrophotometer (Beckman Instruments Inc., Fullerto CA, USA) at 260nm. To check for degradation of the DNA, the samples were loaded on a $1 \%$ agarose gel $1 \mathrm{X}$ TAE $(45 \mathrm{mM}$ Tris-acetate, $1 \mathrm{mM}$ EDTA, pH 8) and electrophoresed.

\section{RAPD-PCR analysis}

RAPD-PCR analysis was according to Guthrie et al. (1992). DNA primers tested in this study were purchased from Operon Technologies (Alamada, California, USA) and each is 10 nucleotides long. Two concentrations of each template DNA (24 ng and $96 \mathrm{ng}$ per reaction) were used to test reproducibility and eliminate sporadic amplification products from the analysis. One hundred (100) primers OPA, OPY, OPQ, OPX, and OPW series 
Table 2. Oligonucleotide primers that showed genetic discrimination among the isolates.

\begin{tabular}{|l|l|c|c|c|}
\hline S/N & Operon code & Nucleotide sequence (5' to 3') & No of fragments amplified & No of polymorphic bands \\
\hline 1 & OPX-04 & CCGCTACCGA & 12 & 6 \\
2 & OPX-12 & TCGCCAGCCA & 14 & 9 \\
3 & OPX-17 & GACACGGACC & 15 & 9 \\
4 & OPX-20 & CCCAGCTAGA & 7 & 5 \\
5 & OPY-01 & GGTGGCATCT & 8 & 3 \\
6 & OPW-07 & CTGGACGTCA & 5 & 3 \\
7 & OPW-09 & GTGACCGAGT & 7 & 5 \\
8 & OPW-10 & TCGCATCCCT & 6 & 2 \\
9 & OPW-11 & CTGATGCGTG & 6 & 3 \\
10 & OPW-13 & CACAGCGACA & 8 & 6 \\
& & Total & 88 & 51 \\
\hline
\end{tabular}

were screened with two isolates (1SaUCH and 4IT) for their to amplify the $S$. aureus DNA. Ten of these primers were found useful and gave polymorphism. These were used in amplifying the DNA from all the isolates. Amplifications were performed in $25 \mu \mathrm{l}$ reaction mixture consisting of genomic DNA, $1 \mathrm{X}$ reaction buffer (Promega), $100 \mu \mathrm{M}$ each of dATP, dCTP, dGTP, and dTTP, $0.2 \mu \mathrm{M}$ primer, 2.5 $\mu \mathrm{M} \mathrm{MgCl} 2$ and $1 \mathrm{U}$ of Taq polymerase (Boehringer, Germany). A single primer was used in each reaction. The reaction mixture was overlaid with $50 \mu \mathrm{l}$ of mineral oil to prevent evaporation. Amplification was performed in a thermowell microtiter plate (Costa Corporation) using a Perkin Elmer programmable Thermal Controller (Model 4800 and 9600). The cycing program was (i) 1 cycle of $94^{\circ} \mathrm{C}$ for $3 \mathrm{~min}$; (ii) 45 cycles of $94^{\circ} \mathrm{C}$ for $1 \mathrm{~min}$ for denaturation, $35^{\circ} \mathrm{C}$ for $1 \mathrm{~min}$ for annealing of primer and $72^{\circ} \mathrm{C}$ for 2 min for extension; and (iii) a final extension at $72^{\circ} \mathrm{C}$ for $7 \mathrm{~min}$. Amplification products were maintained at $4^{\circ} \mathrm{C}$ until electrophoresis.

The reaction products were resolved by electrophoresis in a $1.4 \%$ agarose gel using $1 \mathrm{X}$ TAE buffer at $150 \mathrm{~V}$ for $2 \mathrm{~h}$. A $1-\mathrm{kb}$ ladder (Life Technologies, Gaithersburg, MD, USA) was included as molecular size marker. Gels were visualized by staining with ethidium bromide solution $(0.5 \mu \mathrm{g} / \mathrm{ml})$ and banding patterns were photographed over UV light using a red filter.

\section{Data analysis}

Position of unequivocally scorable RAPD bands were transformed into a binary character matrix ("1" for the presence and "0" for the absence of a band at a particular position). Pairwise distance matrices were compiled by the NTSYS-PC 2.0 software packages (Rohlf, 1993), using the Jaccard coefficient of similarity (Jaccard, 1908). Dendorgrams were created by UPGMA cluster analysis.

\section{RESULTS AND DISCUSSION}

The amplification reactions with the 10 primers generated 88 bands, 51 of which was polymorphic (Table 2) with size range of between 200 and 3,000 bp. According to the pairwise genetic distances among the isolates analyzed at $100 \%$ similarity, all the isolates were classified completely into twelve different groups (Figure 1). At $50 \%$ coefficient of similarity, all the isolates were classified in two major groups. The first major group comprised of mildly and weakly virulent isolates while the second group comprised of highly virulent ones. It was hypothesized that the frequent occurrence of mutants might be responsible for the high level of variation among the isolates.

The results demonstrated that the RAPD technique may be of great use for the classification of $S$. aureus. Obviously, for these patterns to have a practical meaning in the areas of medicine, population biology and epidemiology, specific DNA bands must be related with the virulence genes (Welsh et al., 1990). This could be accomplished by a systematic comparison of DNA band patterns among bacteria contrasting for the different virulence genes. Similar approach has been used to differentiate aggressive from non-aggressive isolates of the oilseed rape pathogen Phoma lingam (Schafer and Wostmeyer, 1992).

The DNA fingerprint defined for each race of $S$. aureus could be useful for the surveillance of epidemiological revolution strategies, medical diagnoses and in the identification of new strains and isolates. The next step would to clone the isolates specific bands (bands with different virulence genes), sequence them and design specify primers for the development of sequence characterized amplified regions which would be much more specific and easier to apply. More research involving additional molecular techniques is needed to confirm if further sub-grouping would be appropriate.

\section{REFERENCES}

Coltman K (1981). Urinary tract infections. New thoughts on an old subject. The Practitioner 223: 351-355.

Delong E F, Wickham GS, Pace NR (1989). DNA fingerprinting using very short random primers. J. Sci. 243: 1360-1363.

Eisenstein BI (1990). Bacterial diseases and control. J. Infectious Dis. 161: 595-602.

Gore LF, Walsh P (1964). Preservation and storage of bacterial cultures 


\section{Afr. J. Biotechnol.}

J. Med. Lab. Technol. 21: 244-246.

Guthrie PAI, Magill CW, Frederiksen RA, Odvody GN (1992). Random amplified polymorphic DNA markers: A system for identifying and differentiating isolates of Colletotrichum graminicola. Phytopathology 82: 832-835.

Jaccard $P$ (1908). Nouvelles recherches sur la distribution florale. Bull. Soc. Vaud. Sci. Nat. 44: 223-270.

Kado Cl, Heskett MG (1970). Selective media for isolation of Agrobacterium,Corynebacterium, Erwinia, Pseudomonas, Xanthomonas. Phypathology .60: 969-976.

Kloos WE, Schleifer KH (1981). The genus Staphylococcus in the prokaryotes : A handbook on habitat, isolation and identification of bacteria. Vols. 1 and 2.

Roeder V, Broda P (1987). Rapid preparation of DNA from filamentous fungi.Letters in Appl. Microb. 1: 17-20.

Rohlf FJ (1993). NTSYS-PC. Numerical taxonomy and multivariate analysis system Version 2.0. Exeter, New York.
Schafer E, Wostmeyer J (1992). Random primer dependent PCR differentiates aggressive and non-aggressive isolates of the oilseed rape pathogen Phoma lingam (Leptosphaeria maculans). J. Phytopathol. 136:124-136.

Sng EH, Yeo KL, Rajan VS (1981). Simple method for detecting penicillinase-producing Neisseria gonorrhoeae and Staphylococcus aureus. Br. J. Veneral Dis. 57: 141-142.

Stokes JE, Ridgway GL (1980). Clinical Bacteriology. Edward Arnold. $5^{\text {th }}$ Edition. pp. 35-50.

Welsh J, McClelland M (1990). Fingerprinting genomes using PCR with arbitrary primers. Nucleic acids Res. 18: 6531-6535.

Woese CR (1986). Evolution in Prokaryotes. Schleifer KH, Stackebrandt $\mathrm{E}(\mathrm{ed})$.Academic Press, London. 